\title{
DZIAEANIA EDUKACYJNO-INFORMACYJNE Prezesa Urzędu Komunikacji Elektronicznej JAKO ELEMENT BUDOWANIA KONKURENCJI \\ W SEKTORZE TELEKOMUNIKACYJNYM
}

\section{Wstęp}

Przystąpienie Polski do Unii Europejskiej wiązało się z dokonaniem wielu zmian w obszarze regulacji sektora telekomunikacyjnego. Adaptacja regulacji sektorowych, stosowanych w Unii Europejskiej, doprowadziła do wzrostu konkurencji na rynku usług telekomunikacyjnych. Spowodowała poprawę dostępności usług, wzrost różnorodności ofert i spadek cen $^{1}$. Istotnym elementem rozwoju konkurencji jest informacja skierowana do konsumenta. Właściwa informacja stanowi gwarancje prawidłowego rozwoju konkurencji, gdyż tylko świadomy konsument może dokonywać właściwych wyborów.

Jednym z głównych obszarów działań Prezesa Urzędu Komunikacji Elektronicznej (dalej jako: Prezes UKE) w dziedzinie budowania konkurencji w sektorze komunikacyjnym jest wzmocnienie pozycji konsumentów na rynku usług telekomunikacyjnych poprzez zwiększenie wśród nich poziomu świadomości ich praw i obowiązków. Działania te mają charakter edukacyjno-informacyjny i prowadzą do intensyfikacji konkurencji rynkowej pod względem jakościowym. Przedsiębiorcy obok akceptowalnego dla konsumenta poziomu cen muszą w swoich ofertach zwrócić uwagę na parametry usług, warunki ich świadczenia oraz jakość obsługi klienta. Wśród podejmowanych przez Prezesa UKE inicjatyw w tej dzie-

*Dr, Uniwersytet Rzeszowski; elzbieta_malecka@interia.eu.

${ }^{1}$ B. Ciesielski, Wptyw integracji z Unią Europejską na rozwój konkurencji w polskim sektorze ustug telekomunikacyjnych, "Zarządzanie Zmianami Zeszyty Naukowe” 2011 z. 3 (53), s. 23. 
dzinie należy wyróżnić Program certyfikacji usług telekomunikacyjnych oraz Centrum Informacji Konsumenckiej.

\section{Program certyfikacji usług telekomunikacyjnych}

Przepisy ustawy z dnia 16 lipca 2004 r. - Prawo telekomunikacyjne ${ }^{2}$ w art. 189 p.t. wskazują że organy administracji łączności jakimi są minister właściwy do spraw łączności oraz Prezes UKE prowadzą politykę regulacyjna, mając na celu w szczególności m. in. wspieranie konkurencji w zakresie dostarczania sieci telekomunikacyjnych, udogodnień towarzyszących lub świadczenia usług telekomunikacyjnych. Jednym z jej elementów jest zapewnienie użytkownikom, także użytkownikom niepełnosprawnym, osiągania maksymalnych korzyści w zakresie cen oraz różnorodności i jakości usług. Osiągnięciu tego celu służą m. in. właśnie działania edukacyjno-informacyjne. Niestety kolejne opracowania związane z sektorami regulacyjnymi, organami łączności ${ }^{3}$ jak i samym prawem telekomunikacyjnym ${ }^{4}$ jedynie wspominają o tej dziedzinie aktywności Prezesa UKE. Odniesienia do podejmowanych przez Prezesa UKE działań edukacyjno-informacyjnych znajdują się w opracowanych przez niego dokumentach ${ }^{5}$.

Bezpośrednim narzędziem oddziaływania na właściwą konkurencję na rynku usług telekomunikacyjnych jest program certyfikacji usług telekomunikacyjnych realizowany przez Prezesa UKE i wymieniony w Po-

${ }^{2}$ Ustawa z dnia 16 lipca 2004 r. - Prawo telekomunikacyjne, Dz. U. z 2014 r. poz. 243, dalej jako: p.t.

${ }^{3}$ Por.: K. Wawrzecki, P. Kleszkowski, Ochrona konsumentów w prawie telekomunikacyjnym. Podstawy prawne, [w:] T. Długosz (red.), Ochrona konkurencji i konsumentów w prawie sektorów infrastrukturalnych, Kraków 2012, s. 64 i nast.; E. Paluch, Prezes Urzędu Komunikacji Elektronicznej oraz Prezes Urzędu Ochrony Konkurencji i Konsumentów jako organy regulacji rynku telekomunikacyjnego [w:] T. Długosz (red.), Ochrona konkurencji i konsumentów..., s. 125 i nast.

${ }^{4}$ Por. S. Piątek, Prawo telekomunikacyjne. Komentarz, Warszawa 2013, s. 1136 - 1171; K. Kawałek, M. Rogalski, Prawo telekomunikacyjne. Komentarz, Warszawa 2010, s. 997-1034; A. Krasuski, Prawo telekomunikacyjne. Komentarz, Warszawa 2015, s. 1467-1506.

${ }^{5}$ Prezes UKE, Strategia regulacyjna do roku 2015, Warszawa 2012, s. 27, http://www.uke. gov.pl [dostęp: 1.12.2015 r.] https://www.uke.gov.pl/files/?id_plik=10971. 
lityce konkurencji na lata 2011-20136. W dokumencie Polityka konkurencji na lata 2014-20187 znajduje się wskazanie, że Prezes UKE planuje kontynuację dotychczasowych działań, wyszczególnionych w Polityce konkurencji na lata 2011-2013. W 2013 r. program certyfikacji usług telekomunikacyjnych został zaktualizowany i stale jest kontynuowany. Program obecnie obejmuje pięć filarów: Bezpieczny Internet (zwiększenie bezpieczeństwa), Senior (wyrównywanie szans dla osób starszych) oraz Porównywarka Ofert (zwiększenie informacji o ofertach telekomunikacyjnych). W lipcu 2015 r. Prezes UKE wprowadził dwie nowe kategorie Programu Certyfikat Prezesa UKE - Przyjaźni Niepełnosprawnym oraz Junior. Zgodnie z danymi zawartymi na stronie Urzędu Komunikacji Elektronicznej, Program certyfikacji usług ma na celu wspieranie równoprawnej i skutecznej konkurencji w zakresie świadczenia usług telekomunikacyjnych. Pomaga także w zapewnieniu użytkownikom, w zależności od wieku i sytuacji życiowej, jak najlepszej ochrony przed nadużyciami. Program Certyfikat Prezesa UKE w każdej kategorii kierowany jest do wszystkich przedsiębiorców telekomunikacyjnych, spełniających określone przez Prezesa UKE warunki ${ }^{8}$.

W artykule analizie zostały poddane regulaminy programów certyfikacji usług telekomunikacyjnych w kategoriach: Bezpieczny Internet, Senior, Porównywarka Ofert, Przyjaźni Niepełnosprawnym oraz Junior, które są dostępne w formie elektronicznej na stronie Urzędu'. Wszystkie Regulaminy mają podobną konstrukcję i zawierają analogiczne przepisy. Dokumenty te składają się z czterech części: I Podmiot przyznający certyfikat; II Cel i opis Programu "Certyfikat Prezesa UKE”; III Warunki uczestnictwa; IV Procedura przyznania certyfikatu. Przy czym, znaczące różnice wypływające z danej kategorii rysują się w części szczegółowej dotyczącej celu i warunków uczestnictwa w Programie (tj. część 2 i 3 Regulaminów).

${ }^{6}$ UOKiK, Polityka konkurencji na lata 2011-2013, Warszawa 2011, s. 16-19, http://www. uokik.pl [dostęp: 1.12.2015 r.] https://uokik.gov.pl/download.php?plik=10111.

7 UOKiK, Polityka konkurencji na lata 2014-2018, Warszawa 2014, s. 112, http://www. uokik.pl [dostęp: 1.12.2015 r.] https://uokik.gov.pl/download.php?plik=14691.

8 Dane za stroną: http://www.uke.gov.pl [dostęp: 1.12.2015 r.] http://uke.gov.pl/nowe-kategorie-certyfikatu-prezesa-uke-przyjazni-niepelnosprawnym-oraz-junior-16381.

${ }^{9}$ http://www.uke.gov.pl [dostęp: 1.12.2015 r.]. 


\section{Procedura przyznania certyfikatu}

Zgodnie z przepisami zawartymi w Regulaminach do Programu certyfikacji usług telekomunikacyjnych mogą przystąpić wszyscy przedsiębiorcy telekomunikacyjni, zarówno operatorzy jak i dostawcy usług spełniający określone przez Prezesa UKE warunki dla danej kategorii Programu. Udział w Programie jest dobrowolny i nie powoduje konieczności zmiany Regulaminu świadczenia usług telekomunikacyjnych.

Certyfikat nadawany jest na okres jednego roku. Termin ten może być przedłużony na kolejny rok. W tym celu przedsiębiorca powinien złożyć ponownie wniosek $\mathrm{w}$ terminie przewidzianym do 30 września każdego roku, poprzedzającego rok, na który ma być przyznany certyfikat Prezesa UKE. Termin ten jest tożsamy z terminem składania wniosków po raz pierwszy.

Usługodawca sam podejmuje decyzję, które $\mathrm{z}$ oferowanych usług będzie sprzedawał w ramach Programu. Należy zaznaczyć, że Certyfikat przyznawany jest usługodawcy za spełnienie warunków Programu, jednakże to do usługodawcy należy decyzja, do której grupy usług/ofert Certyfikat będzie miał zastosowanie. Usługi te muszą spełniać warunki danego Certyfikatu.

Usługodawca może wykorzystywać znak Certyfikatu do promocji, reklamy oraz innych działan marketingowych, $\mathrm{w}$ tym informacyjnych tworzących wizerunek firmy lub samej usługi, której znak dotyczy (cz. I pkt 2 Regulaminu Programu "Certyfikat Prezesa UKE” w kategorii Senior ${ }^{10}$.

Kwestie związane ze składaniem wniosków zostały unormowane w cz. IV pkt 1 Regulaminów. Wnioski można składać do 30 września każdego roku, poprzedzającego rok, na który ma być przyznany certyfikat Prezesa UKE. Wypełniony wniosek Wnioskodawca składa do Prezesa UKE za pośrednictwem poczty elektronicznej, listownie, faksem lub osobiście.

Problematyka załączników do wniosku została ujęta w cz. IV pkt 2 Regulaminów. Na podstawie analizy treści tych dokumentów można wyszczególnić kilka rodzajów załączników, które powtarzają się z drobnymi

${ }^{10}$ Por. cz. I pkt 2 Regulaminu Programu „Certyfikat Prezesa UKE” w kategorii Bezpieczny Internet; cz. I pkt 2 Regulaminu Programu "Certyfikat Prezesa UKE” w kategorii Junior; cz. I pkt 2 Regulaminu Programu „Certyfikat Prezesa UKE” w kategorii Porównywarka Ofert; cz. I pkt 2 Regulaminu Programu „Certyfikat Prezesa UKE” w kategorii Przyjaźni Niepełnosprawnym. 
zmianami wywołanymi specyfiką danej kategorii w analizowanych przepisach. Są to: 1. podpisane oświadczenie reprezentanta przedsiębiorcy, iż zapoznał się z warunkami Programu oraz Regulaminu i akceptuje jego wszystkie zapisy; 2.Regulamin Świadczenia Usług Telekomunikacyjnych; 3.Wzór umowy; 4.Cennik; 5.Oferta handlowa; 6.Udostępniany użytkownikom Podręcznik/Poradnik dotyczący korzystania z mediów elektronicznych; 7. Wypełniona ankieta Certyfikatu ${ }^{11}$.

Prezes UKE rozpatruje wniosek najpóźniej w ciągu 90 dni od dnia jego złożenia. Rozpatrzenie wniosku następuje na podstawie przekazanej dokumentacji. W przypadku konieczności uzupełnienia informacji, Urząd wskazuje drogą elektroniczną zakres informacji, jakie należy dostarczyć wyznaczając jednocześnie termin ich uzupełnienia. W przypadku braku uzupełnienia o dodatkowe informacje wniosek pozostawiany jest bez rozpatrzenia. W sytuacji, gdy przedsiębiorca nie spełnia któregoś z określonych w Programie wymogów, Prezes UKE wskazuje stwierdzone nieprawidłowości oraz $\mathrm{w}$ porozumieniu $\mathrm{z}$ przedsiębiorcą ustala termin ich usunięcia. Wnioski niespełniające kryteriów formalnych pozostawione są bez rozpoznania, chyba, że Prezes UKE wezwie przedsiębiorcę do ich uzupełnienia, a wezwany podmiot uczyni to $\mathrm{w}$ wyznaczonym terminie. Wnioski rozpatrywane są pod względem kryteriów formalnych i merytorycznych. Kryteria formalne obejmują kompletność i poprawność wypełnienia wniosku oraz dokumentacji. Kryteria merytoryczne dotyczą m. in.: zgodności przekazanej dokumentacji z ustawą z dnia 16 lipca 2004 r -. Prawo telekomunikacyjne oraz sposób realizacji wymogów a także osiągnięty tym sposobem cel (cz. IV pkt 1,4,5 Regulaminów).

Po pozytywnej weryfikacji Wnioskodawca jest niezwłocznie o tym poinformowany i zaproszony na uroczyste wręczenie Certyfikatu przez Prezesa UKE. Dodatkowo Prezes UKE publikuje na stronie internetowej Urzędu listę przedsiębiorców posiadających Certyfikat, wraz z informacjami obejmującymi datę jego nadania oraz okres ważności Certyfikatu. Taka lista może być publikowana również w innych środkach masowego przekazu. Publikowana jest także lista przedsiębiorców, którym został odebrany Certyfikat w trakcie trwania Programu wraz uzasadnieniem odebrania znaku (cz. IV pkt 3 Regulaminów).

11 Odmiennie cz. IV Regulaminu Programu „Certyfikat Prezesa UKE” w kategorii Porównywarka Ofert; cz. IV pkt 2 Regulaminu Programu „Certyfikat Prezesa UKE” w kategorii Przyjaźni Niepełnosprawnym. 
Przedsiębiorca, któremu został przyznany Certyfikat zobowiązany jest raz na pół roku przedstawiać Prezesowi UKE sprawozdania z realizacji zasad Programu. Podstawą sprawozdania powinny być dane jakościowe oraz ilościowe z dotychczasowej realizacji wymogów Programu. Prezes UKE zachowuje sobie prawo do weryfikacji spełniania przez przedsiębiorcę warunków danego Certyfikatu. W przypadku, gdy do Urzędu Komunikacji Elektronicznej będą docierać sygnały od konsumentów dotyczące możliwych nieprawidłowości, Prezes UKE może wezwać przedsiębiorcę do złożenia wyjaśnień w sprawie lub zlecić audyt operatora $\mathrm{w}$ omawianym zakresie. Prezes UKE może jednocześnie skorzystać z obu tych uprawnień (cz. IV pkt 6 Regulaminów).

Zasady przedłużania ważności Certyfikatu oraz zasady odebrania Certyfikatu w przypadku naruszenia przez przedsiębiorcę warunków Programu zostały unormowane w cz. IV pkt 6 i 7 Regulaminów ${ }^{12}$. Przedsiębiorca, który chce przedłużyć ważność otrzymanego Certyfikatu zobowiązany jest ponownie przedłożyć Prezesowi UKE wniosek o nadanie Certyfikatu wraz z kompletem wymaganej dokumentacji oraz sprawozdanie ze swoich działań związanych z danym Certyfikatem za rok ubiegły. W sprawozdaniu powinny się znaleźć informacje o podjętych przez przedsiębiorcę działaniach na rzecz poprawy bezpieczeństwa mediów elektronicznych oraz podnoszenia jakości świadczonych usług telekomunikacyjnych. Brak ponownego zgłoszenia do Urzędu Komunikacji Elektronicznej skutkuje utratą ważności Certyfikatu oraz obowiązkiem zaprzestania wykorzystywania znaku przez przedsiębiorcę. Jest on również zobowiązany do wycofania znaku ze wszystkich materiałów informacyjnych przedsiębiorcy podawanych do publicznej wiadomości.

W przypadku naruszenia przez przedsiębiorcę warunków przystąpienia do Programu, Urzędu Komunikacji Elektronicznej wezwie go do usunięcia nieprawidłowości oraz określi termin ich usunięcia. Jednocześnie Urząd może także zlecić audyt w tym zakresie. Jeśli wskazane przez Urzędu Komunikacji Elektronicznej nieprawidłowości nie zostaną usunięte $\mathrm{w}$ wyznaczonym terminie, Certyfikat zostaje odebrany. $\mathrm{Z}$ chwilą odebrania Certyfikatu przedsiębiorca jest zobowiązany do zaprzestania wykorzystywania znaku oraz wycofania go ze wszystkich publicznie dostępnych materiałów informacyjnych. Dalsze posługiwanie się nim bez

12 Odmiennie Regulamin Programu „Certyfikat Prezesa UKE” w kategorii Porównywarka Ofert (cz. IV pkt 3 i 5); Regulamin Programu „Certyfikat Prezesa UKE” w kategorii Przyjaźni Niepełnosprawnym (cz. IV pkt 4 i 6). 
zgody Urzędu Komunikacji Elektronicznej stanowi naruszenie praw do znaku.

Analizując treść Regulaminów można dopatrzeć się pewnej niekonsekwencji. We wszystkich przywołanych przepisach pojawia się pojęcie decyzji Prezesa UKE o przyznaniu Certyfikatu, bądź o odmowie jego przyznania. Tylko Regulamin Programu „Certyfikat Prezesa UKE” w kategorii Porównywarka Ofert zawiera regulacje związane z postępowaniem odwoławczym w tej sprawie (wydaje się, że przepisy te można stosować na zasadzie analogii w ramach każdej innej kategorii Certyfikatu). W cz. IV w dziale Opis akredytacji, krok 6 znajduje się informacja, że „przyznanie Certyfikatu Prezesa UKE (lub odmowa jego przyznania) nie nosi znamion decyzji administracyjnej, jednak podmioty, które są przekonane, że zostały poszkodowane podczas procesu oceny mogą złożyć odwołanie bezpośrednio do Prezesa UKE w terminie 14 dni od daty otrzymania odmowy przyznania Certyfikatu Prezesa UKE". Na uwagę zasługuje fakt, że w całym tym dokumencie znajduje się dużo odesłań do „decyzji Prezesa UKE o przyznaniu Certyfikatu".

Takie ukształtowanie przepisów prowadzi do wewnętrznej sprzeczności całego dokumentu. Dlatego bardziej fortunnym stwierdzeniem niż „decyzja o przyznaniu Certyfikatu” byłoby określenie „przyznanie Certyfikatu przez Prezesa UKE". Podmioty, które uważają że zostały poszkodowane podczas procesu oceny mogą złożyć odwołanie do tego samego organu, który dokonał tego procesu, czyli do Prezesa UKE. Poza faktem, że jeżeli przyznanie certyfikatu nie nosi znamion decyzji, co wyklucza niejako możliwość odwołania, uwagę zwraca kwestia, że organem rozpatrującym jest Prezes UKE. W tej sytuacji poszkodowany podmiot może jedynie złożyć wniosek o ponowne rozpatrzenie sprawy ${ }^{13}$.

\section{Certyfikowanie usług telekomunikacyjnych w kategorii Bezpieczny Internet}

Celem certyfikowania usług telekomunikacyjnych w kategorii Bezpieczny Internet jest wspieranie działań przedsiębiorców telekomunika-

${ }^{13}$ Por. Z. Kmieciak, Wniosek o ponowne rozpatrzenie sprawy w k.p.a. (Odwołanie czy remonstracja?), „Państwo i Prawo” 2008, z. 3, s. 19-35. 
cyjnych związanych z podnoszeniem jakości świadczonych przez nich usług. Ma to ścisły związek z zapewnieniem bezpieczeństwa użytkowników w szczególności dzieci i młodzieży. Dodatkowe znaczenie ma zwrócenie uwagi użytkowników na problem związany z ich bezpieczeństwem $\mathrm{w}$ sieci oraz zachęcenie ich do korzystania $\mathrm{z}$ dostępnych na rynku narzędzi mogących zapewnić możliwie najwyższy poziom zabezpieczenia przed przestępczością w sieci (cz. II pkt 1 Regulaminu Programu „Certyfikat Prezesa UKE" w kategorii Bezpieczny Internet).

W warunkach uczestnictwa Programu „Certyfikat Prezesa UKE” w kategorii Bezpieczny Internet zostały wymienione następujące wymagania:

1. organizacja szkoleń dotyczących zagrożeń i przemocy w sieci przez przedsiębiorców telekomunikacyjnych w szkołach;

2. udostępnienie użytkownikom usług telekomunikacyjnych poradników dotyczących bezpieczeństwa w sieci Internet;

3. udostępnienie odrębnego adresu mailowego dla użytkowników, pod którym konsumenci będą mogli uzyskać podstawowe informacje dotyczące bezpiecznego użytkowania sieci Internet, dane teleadresowe organizacji niosących pomoc ofiarom przemocy w sieci oraz przestępstw internetowych;

4. bezpłatne udostępnienie narzędzi umożliwiających ochronę komputera oraz dostępu dzieci i osób niepełnoletnich do treści przeznaczonych dla osób dorosłych (programy filtrujące, antywirusy oraz programy antyspamowe);

5. udostępnianie użytkownikom usług telekomunikacyjnych informacji na witrynach www o konsekwencjach prawnych oraz sposobach przeciwdziałania treściom naruszającym dobra osobiste użytkowników usług telekomunikacyjnych lub innym treściom o charakterze oskarżającym, wyszydzającym i poniżającym grupy oraz jednostki z takich jak powodów jak przynależność narodowa, rasowa, etniczna i religijna, a także płeć, preferencje seksualne, kalectwo oraz danych teleadresowych organizacji niosących pomoc ofiarom takich treści (cz. III w/w Regulaminu). 


\section{Certyfikowanie usług telekomunikacyjnych w kategorii Przyjaźni Niepełnosprawnym}

Podstawą Programu „Certyfikat Prezesa UKE” w kategorii „Przyjaźni Niepełnosprawnym" jest potrzeba wyrównywania szans osób niepełnosprawnych w dostępie do usług telekomunikacyjnych. Zgodnie z przepisami cz. II pkt 1 Regulaminu tego Programu główny jego cel stanowi nakłonienie przedsiębiorców telekomunikacyjnych (nie tylko dostawców publicznie dostępnych usług telefonicznych, do których odnosi się art. 79c ust. 1 p.t.) do tworzenia w ramach swojej oferty różnego rodzaju udogodnień dla osób niepełnosprawnych w dostępie do świadczonych usług. Przedsiębiorcy muszą przy tym uwzględniać specjalne potrzeby osób niepełnosprawnych $\mathrm{w}$ zakresie możliwości korzystania $\mathrm{z}$ oferty operatorów telekomunikacyjnych oraz założenie przeciwdziałania wykluczeniu cyfrowemu, a zarazem społecznemu tych osób.

Certyfikat Prezesa UKE w ramach tego Programu przyznawany jest po spełnieniu określonych warunków. Podstawowym wymogiem uczestnictwa w nim jest oferowanie osobom niepełnosprawnym rozwiązań czy też udogodnień wykraczających poza aktualne wymogi prawa w tym zakresie, wynikające z art. 79c ust. 1 p.t. ${ }^{14}$ oraz z Rozporządzenia Ministra Administracji i Cyfryzacji z dnia 26 marca 2014 r. w sprawie szczegółowych wymagań dotyczących świadczenia udogodnień dla osób niepełnosprawnych przez dostawców publicznie dostępnych usług telekomunikacyjnych ${ }^{15}$ wydanego na podstawie art. 79 c ust. 3 p.t.

Przepisy cz. III Regulaminu tego Programu wskazują że Prezes UKE oczekuje od przedsiębiorców „postawy przyjaznej” osobom niepełnosprawnym. Odzwierciedleniem natomiast tej postawy sa dobrowolne oferty im dedykowane, które wykraczają poza katalog udogodnień określony w prawie. Na uwagę zasługuje fakt, że Prezes UKE pozostawia przedsię-

${ }^{14}$ Przepis art. 79c ust. 1 p.t.: Dostawca publicznie dostępnych usług telefonicznych zapewnia, w miarę możliwości technicznych, użytkownikom końcowym będącym osobami niepełnosprawnymi dostęp do świadczonych przez siebie usług telefonicznych równoważny dostępowi do usług telefonicznych, z jakiego korzysta większość użytkowników końcowych.

15 Rozporządzenie Ministra Administracji i Cyfryzacji z dnia 26 marca 2014 r. w sprawie szczegółowych wymagań dotyczących świadczenia udogodnień dla osób niepełnosprawnych przez dostawców publicznie dostępnych usług telekomunikacyjnych, Dz. U. 2014 r. poz. 464, dalej jako: Rozporządzenie. 
biorcom dowolność w formułowaniu ofert udogodnień uczestniczących w Programie. Otwarty jest również zakres podmiotowy jak i przedmiotowy tych rozwiązań, przy czym:

- w ramach zakresu podmiotowego - oferta powinna być skierowana do osób niepełnosprawnych o różnym rodzaju i stopniu niepełnosprawności (co najmniej do 2 różnych grup osób niepełnosprawnych, biorąc pod uwagę rodzaj niepełnosprawności - przy czym bezwzględnie powinny być uwzględnione osoby niewidome i niesłyszące oraz 2 różnych grup osób niepełnosprawnych, biorąc pod uwagę stopień niepełnosprawności);

- w ramach zakresu przedmiotowego - oferta powinna wykraczać poza ramy określone w art. 79c ust. 1 p.t. oraz w Rozporządzeniu;

- oferta powinna funkcjonować na rynku minimum 3 miesiące przed zgłoszeniem do Programu (cz. III Regulaminu).

\section{Certyfikowanie usług telekomunikacyjnych w kategorii Senior}

Zadaniem Programu "Certyfikat Prezesa UKE” w kategorii Senior jest zwiększenie aktywności osób starszych na rynku usług telekomunikacyjnych. Jego głównym celem jest stworzenie specjalnej obsługi i oferty handlowej dla tej grupy osób oraz poprawa kwalifikacji, umiejętności i efektywności funkcjonowania ludzi starszych na rynku usług telekomunikacyjnych. Program nie wskazuje na wiek seniorów, to usługodawca sam powinien wskazać wiek klienta, który może skorzystać z oferty w ramach Certyfikatu w kategorii Senior. W efekcie tych działań osoby starsze będą mogły korzystać z nowych technologii oraz nowych tańszych form komunikacji (cz. II pkt 1 Regulaminu).

Warunki uczestnictwa w tym Programie obejmują: 1. wsparcie sprzedażowe/obsługa klienta, 2. wsparcie techniczne, 3. wsparcie szkoleniowe, 4. konfigurację usługi, 5. umowę na próbę, łącząca się z możliwością wypowiedzenia umowy w ciągu $30 \mathrm{dni}$ bez konsekwencji (kar) finansowych, 6. „wypróbuj zanim kupisz” czyli praktyczne szkolenie z obsługi telefonu lub komputera przed zakupem sprzętu, 7. odpowiednia do potrzeb oferta sprzętowa, 8. przejrzystość warunków umowy (cz. III Regulaminu). 


\section{Certyfikowanie usług telekomunikacyjnych w kategorii Porównywarka Ofert}

Prezes UKE podejmując działania związane z akredytacją serwisów porównawczych dą̇̇y do zwiększania dostępności informacji o ofertach, jednocześnie stwarzając konsumentom możliwość dokonania jak najlepszego wyboru wśród usług dostępnych na rynku telekomunikacyjnym. W związku z tym Program "Certyfikat Prezesa UKE” w kategorii Porównywarka Ofert ma na celu: udzielanie akredytacji serwisom porównującym ceny usług telekomunikacyjnych oraz zapewnienie wykorzystania w procesie akredytacji kryteriów obiektywności i przejrzystości. Ponadto, celem jest również gwarantowanie, że kryteria na podstawie których oceniani są wnioskodawcy zapewniają użytkownikom końcowym rzetelne i łatwe do wykorzystania narzędzia oraz zwiększają świadomość użytkowników końcowych (cz. II pkt 1 Regulaminu).

W Programie mogą wziąć udział przedsiębiorcy oferujący serwisy internetowe, które pozwalają porównywać oferty w segmencie telekomunikacji. Serwisy te muszą spełniać określone kryteria jakościowe. Są to dostępność, przejrzystość oraz kompleksowość i wszechstronność. Należy podkreślić, że porównanie nie może pomijać żadnego dostawcy usług, który przejawia gotowość porównania swojej oferty z innymi ofertami dostępnymi na rynku. Istnieje przy tym wymóg spełniania wymogów postawionych przez serwis. Porównanie ofert telekomunikacyjnych musi być kompleksowe. Użytkownicy końcowi powinni być zapoznani także z innymi niż tylko cena usług czynnikami, które mogliby wziąć pod uwagę decydując się na wybór konkretnej oferty (cz. III Regulaminu).

\section{Certyfikowanie usług telekomunikacyjnych w kategorii Junior}

Zgodnie z Regulaminem Programu „Certyfikat Prezesa UKE” w kategorii Junior głównym jego celem jest zachęcenie przedsiębiorców, oferujących swoje usługi na rynku telekomunikacyjnym do stworzenia specjalnej oferty dedykowanej dla najmłodszych użytkowników usług telekomunikacyjnych. Powinna ona zapewniać bezpłatną i automatyczną bloka- 
dę połączeń z numerami o podwyższonej opłacie (Premium Rate) $)^{16}$ oraz bezpłatną i automatyczną blokadę zapewniającą brak dostępu do nieodpowiednich treści za pośrednictwem sieci internetowej. Dodatkowymi celami jest promocja działań przedsiębiorców, którzy otrzymali Certyfikat Prezesa UKE oraz zainteresowanie rodziców ofertą skierowaną do najmłodszych użytkowników (cz. II pkt 1 Regulaminu).

Warunki uczestnictwa w Programie „Certyfikat Prezesa UKE" w kategorii Junior obejmują udostępnianie poradników o tematyce dotyczącej ochrony małoletnich przed dostępem do nieodpowiednich treści za pośrednictwem Internetu i usług Premium Rate. Poradniki te mogą być udostępniane w postaci elektronicznej lub papierowej. Ponadto, organizowanie prelekcji i warsztatów edukacyjnych dla małoletnich i ich opiekunów odnośnie potencjalnych zagrożeń i bezpiecznego korzystania z usług telekomunikacyjnych oraz udostępnianie im dedykowanego kontaktu w celu możliwości zgłoszenia dostawcy usług nieprawidłowości w działaniu usług i pojawiających się zagrożeń. Podstawowe znaczenie ma umożliwienie zakupu startera $\mathrm{z}$ oferty dostawcy usług, który zapewniać będzie: bezpłatną i automatyczną blokadę połączeń z numerami o podwyższonej opłacie (Premium Rate) oraz brak dostępu do nieodpowiednich treści za pośrednictwem sieci Internet (cz. III Regulaminu).

\section{Centrum Informacji Konsumenckiej}

Kolejną istotną inicjatywą Prezesa UKE związaną z ochroną interesów konsumentów jest rozwój Centrum Informacji Konsumenckiej, w skład którego wchodzi m.in. strona internetowa www.cik.uke.gov.pl oraz infolinia konsumencka, na której eksperci UKE udzielają porad ${ }^{17}$.

Informacje Prezesa UKE ważne dla konsumentów są zamieszczane i aktualizowane stronie internetowej www.cik.uke.gov.pl, gdzie są publikowane m.in. odpowiedzi na najczęściej zadawane przez konsumentów pytania. W ramach tej strony podawane są również informacje dotyczące zmian zachodzących na rynku usług telekomunikacyjnych, związanych

${ }^{16}$ Zob.: A. Szulakowska, M. Cichy, Premium Rate - rozwój i perspektywy regulacji ustug o podwyższonej opłacie, [w:] A. Walaszek-Pyzioł (red.), Regulacja w sektorze energetycznym, Warszawa 2013 r., s. 459-473.

17 UOKiK, Polityka konkurencji na lata 2014-2018..., s. 113. 
z nim ważnych wydarzeń oraz ostrzeżenia przed różnego rodzaju pojawiającymi się zagrożeniami. Do wiadomości podawane są także działania podejmowane przez Urząd Komunikacji Elektronicznej, które mają na celu kształtowanie polityki konsumenckiej oraz zwiększenie konkurencyjności na rynku usług telekomunikacyjnych. Na stronie tej użytkownicy mogą także znaleźć informacje dotyczące sposobów dochodzenia swoich roszczeń od dostawców usług telekomunikacyjnych ${ }^{18}$.

Od dnia 1 stycznia 2013 r. Centrum Informacji Konsumenckiej zostało rozbudowane o internetowy formularz kontaktowy z narzędziem kategoryzującym oraz dedykowanym adresem e-mail: cik@uke.gov.pl.W ten sposób konsumenci łatwo i szybko mogą złożyć wniosek o interwencję Prezesa UKE lub zadać pytanie m.in. w zakresie zasad korzystania z usług telekomunikacyjnych oraz dochodzenia praw w sporach $\mathrm{z}$ dostawcami usług telekomunikacyjnych. Wykorzystanie formularza kontaktowego oraz narzędzia kategoryzującego wpływające sprawy, przekłada się na szybsze oraz precyzyjniejsze definiowanie problemów występujących na rynku usług telekomunikacyjnych i podejmowanie odpowiednich interwencji przez Prezesa UKE ${ }^{19}$.

Obok opisanych udogodnień Prezes UKE nadal publikuje informacje dotyczące podstawowych praw i obowiązków abonentów publicznie dostępnych usług telekomunikacyjnych w Biuletynie UKE oraz na stronach internetowych UKE.

\section{Zakończenie}

W ramach działań edukacyjno-informacyjnych Prezesa UKE funkcjonuje Program certyfikacji usług telekomunikacyjnych oraz Centrum Informacji Konsumenckiej. W literaturze tematyka ta jest jedynie sygnalizowana, a najwięcej informacji i odniesień znajduje się w dokumentach wydanych przez Urząd Ochrony Konkurencji i Konsumentów oraz Prezesa UKE. Większość danych jest dostępna w formie elektronicznej na stronach Urzędu Komunikacji Elektronicznej. Z analizy wykorzystanych w artykule Regulaminów Programu wynika, że powinny zostać one zmo-

${ }^{18}$ Dane za stroną: http://www.cik.uke.gov.pl/dzialania-uke-na-rzecz-konsumentow15604 [dostęp 3.12.2015 r.].

19 http://www.uke.gov.pl/formularz [dostęp 3.12.2015 r.]. 
dyfikowane. Należy zrezygnować z określenia „decyzja o przyznaniu/ odmowie przyznania Certyfikatu” na rzecz określenia „przyznanie/odmowa przyznania Certyfikatu" oraz odpowiednio dostosować przepisy dotyczące odwołań w kierunku instytucji wniosku o ponowne rozpatrzenie sprawy.

Opisane działania edukacyjno-informacyjne Prezesa UKE należy ocenić pozytywnie, gdyż poprzez wzrost świadomości konsumentów bezpośrednio przyczyniają się do rozwoju konkurencji w sektorze telekomunikacyjnym.

Słowa kluczowe: Prezes UKE, usługi telekomunikacyjne

\section{Bibliografia}

Ciesielski B., Wpływ integracji z Unia Europejska na rozwój konkurencji w polskim sektorze usług telekomunikacyjnych, "Zarządzanie Zmianami Zeszyty Naukowe" 2011 z. 3 (53);

Kawałek K., Rogalski M., Prawo telekomunikacyjne. Komentarz, Warszawa 2010;

Kmieciak Z., Wniosek o ponowne rozpatrzenie sprawy w k.p.a. (Odwołanie czy remonstracja?), „Państwo i Prawo” 2008, z. 3;

Krasuski A., Prawo telekomunikacyjne. Komentarz, Warszawa 2015;

Paluch E., Prezes Urzędu Komunikacji Elektronicznej oraz Prezes Urzędu Ochrony Konkurencji i Konsumentów jako organy regulacji rynku telekomunikacyjnego, [w:] T. Długosz (red.), Ochrona konkurencji i konsumentów w prawie sektorów infrastrukturalnych, Kraków 2012;

Piątek S., Prawo telekomunikacyjne. Komentarz, Warszawa 2013;

Prezes UKE, Strategia regulacyjna do roku 2015, Warszawa 2012;

Regulamin Programu „Certyfikat Prezesa UKE” w kategorii Bezpieczny Internet https://www.uke.gov.pl/files/?id_plik=20177;

Regulamin Programu "Certyfikat Prezesa UKE” w kategorii Junior http:// www.uke.gov.pl/files/?id_plik=20197;

Regulamin Programu „Certyfikat Prezesa UKE” w kategorii Porównywarka Ofert http://uke.gov.pl/files/?id_plik=20198;

Regulamin Programu „Certyfikat Prezesa UKE” w kategorii Przyjaźni Niepełnosprawnym http://uke.gov.pl/files/?id_plik=20199;

Regulamin Programu "Certyfikat Prezesa UKE” w kategorii Senior http:// uke.gov.pl/files/?id_plik=20200;

Szulakowska A., Cichy M., Premium Rate - rozwój i perspektywy regulacji ustug o podwyższonej optacie, [w:] A. Walaszek-Pyzioł (red.), Regulacja w sektorze energetycznym, Warszawa 2013 r.; 
UOKiK, Polityka konkurencji na lata 2011-2013, Warszawa 2011 https://uokik. gov.pl/download.php?plik=10111;

UOKiK, Polityka konkurencji na lata 2014-2018, Warszawa 2014 https://uokik. gov.pl/download.php?plik=14688;

Wawrzecki K., Kleszkowski P., Ochrona konsumentów w prawie telekomunikacyjnym. Podstawy prawne [w:] T. Długosz (red.), Ochrona konkurencji i konsumentów w prawie sektorów infrastrukturalnych, Kraków 2012.

\section{EDUCATIONAL AND INFORMATIVE ACTIONS OF THE PRESIDENT OF THE OFFICE OF ELECTRONIC COMMUNICATIONS AS CONTRIBUTIONS TO BUILDING COMPETITION IN THE SECTOR OF TELECOMMUNICATIONS}

\section{S u m m a r y}

The article presents educational and informative actions taken up by the President of the Office of Electronic Communications aimed at increasing the awareness of consumers and developing pro-competition attitudes of telecommunications service provides. The detailed description includes such initiatives as the Programme for Certification of Telecommunications Services, realised in five categories, and the Centre for Consumer Information, including a website and a consumer hotline.

Keywords: President of the Office of Electronic Communications, telecommunications services

\section{ИНФОРМАЦИОННО-ОБРАЗОВАТЕДЬНЫЕ ДЕЙСТВИЯ ПРЕЗИДЕНТА УПРАВ АЕНИЯ ЭЯЕКТРОННОЙ КОММУНИКАЦИИ \\ КАК ЭДЕМЕНТ СОЗДАНИЯ КОНКУРЕНЦИИ \\ В СЕКТОРЕ ТЕЯЕКОММУНИКАЦИЙ}

$$
\text { P е } 3 \text { ro м е }
$$

В статье представлены информационно-образовательные действия Президента Управления Электронной Коммуникации, которые предусмотренны для повышения осведомленности потребителей и разработки проконкурентных отношений между поставщиками телекоммуникационных услуг. Подробно описаны такие инициативы, как Программа сертификации телекоммуникационных услуг, которая реализуется в пяти категориях, и Центр Информации для Потребителей, в том числе веб-сайт и горячая диния.

Ключевые слова: Президент УЭК, телекоммуникациионные услуги 